\title{
A halál nyomai
}

\author{
LIBICKI ÉVA ${ }^{1}$
}

\begin{abstract}
„Fenyőfák. Minden alkalommal, amikor megérzem gyantaszerü illatukat, a halálra gondolok. Ez az érzés elkerülhetetlen. Azok után, hogy számtalan órát töltöttem Andalúzia (Dél-Spanyolország) temetôiben, a fenyők illata, különösen, ha a tenger illatával keveredik, mindig eszembe juttatja a halált. A fenyőtoboz, ahogyan egyszer az egyik barátom mondta, a termékenységet, az újjászületést és a halhatatlanságot szimbolizálja - három olyan szó, amely az antropológiában a »jó halálhoz" kapcsolódik, ellentétben a »rossz halállal", amely mindig idő elött, természetellenes módon, váratlanul és távol az otthontól következik be." (Perl 2019: 7)²
\end{abstract}

A disszertáció megírását a szerző kíváncsisága vezérelte: mi történik azokkal a holttestekkel, amelyeket a víz sodor partra a dél-európai strandokon? Ez nem ritka jelenség, hiszen a migrációs nyomás Marokkó felől folyamatos (Bachelet 2016), az európai határmenti politika pedig lezáráspárti, továbbá a Spanyolország és Marokkó közötti bonyolult, de közben szinte kapcsolat nélküli helyzet sem csökkenti ezeket a feszültségeket.

A 2003-ban, Rota városa mellett történt hajószerencsétlenséget alapul véve a szerző a munkájában azt mutatja be, hogy a szabálytalan határátkelések olyan események, amelyek képesek az embereket megbélyegezni. Nem azonos módon ugyan, de nem csak azokat, akik ténylegesen átkelnek a határon, hanem azokat is, akiket hátrahagynak, valamint azokat is, akik a víz által partra vetett holttesteket megtalálják. A hajótörés transzlokális utóhatásainak nyomait vizsgálva a disszertáció aprólékos részletességgel tárja fel azt a szociális, politikai és történelmi helyzetet, amely a Földközi-tengeren jelenleg is múködő globális határrendészeti uralmat jellemzi (O’Neill 2012).

\footnotetext{
${ }^{1}$ Debreceni Egyetem Humán Tudományok Doktori Iskola, Szociológia és Társadalompolitika Doktori Program, e-mail: libicki.eva@gmail.com.

${ }^{2}$ Perl, Gerhild: Traces of Death. Exploring Affective Responsiveness Across the Spanish-Moroccan Sea. PhD-disszertáció. A szerzőnek a témához szorosan kapcsolódó művei a következő linken érhetők el: https://unibe-ch.academia.edu/GerhildPerl.
} 


\section{OLVASS FELESLEGESET!}

A disszertáció célja bemutatni a határoknál és a határok által történő erőszakos halált a bonyolult és ellentmondásos beszámolók alapján, amelyet a leginkább érintettek meséltek el. A fókuszt folyamatosan változtatva, nemcsak a 2003-as halálos hajótörés okai kerülnek feltárásra, hanem az is górcső alá kerül, hogy az ilyen halálnak milyen hatásai lehetnek a világban, nem elhanyagolva a nem-szándékolt pozitív kimenetek esélyét sem (Das 2015). Hogyan megy tovább az élet egy hajószerencsétlenség után? Hogyan hat a halál az élőkre, egy halálos hajótörés a határ mindkét oldalán lévő közösségekre? A vízbe fulladtak hogyan „zavarják” az életben maradtak világát? Mit jelent a határoknál, a halál közelében élni? Mit gondolnak az emberek egy ilyen eseményről? Hol kapnak helyet az elbeszélések és az elhallgatások a megemlékezés folyamatában?

Az antropológiában az erőszakos halál gyakran magában foglalja a „rossz halál” kifejezést, amikor a halál idő előtt, véletlenszerűen, természetellenes módon, váratlanul és az otthontól távol következik be (Malpas 2014). A halálnak ez a formája mély sebeket hagy maga után, és átveszi az irányítást az élőktől. Míg a „rossz halálból” nincs újjászületés, addig a ,jó halál” mint a mottóban szereplő fenyőtoboz, a termékenységet, az újjászületést és a halhatatlanságot is szimbolizálja.

\section{A nyomok nyomon követése}

2003. október 25-én, Rota város közelében egy marokkói migránsokat szállító vitorláshajó a haragos tengeren felborult, és 23 ember életét követelte. Annak érdekében, hogy minél többet megtudjunk azokról, akik megfulladtak a hajóbaleset során, és akiknek a holtteste eltűnt az óceánban, vagy azokról, akiket hazaszállítottak Marokkóba, és hamvaikat a spanyol temetőkben szórták szét, vagy akik az üres, jelöletlen temetőfal mögött nyugodnak Los Barriosban, a tanulmány nyomon követi a rotai hajóbalesetet követő események sorát. Igyekszik feltárni a láncolatokat, útvonalakat, szálakat, kapcsolatokat, a mellékszálakhoz kapcsolódó eseteket, amelyek a hajóbalesettel összefüggésbe hozhatóak (De Genova 2017).

A kutatómunka 16 hónapig tartott, 2014 és 2016 között. Ebben az időszakban a szerző helyben lakott, beszélgetett a halászokkal, illetve azokkal az önkéntes segítőkkel, akik elsőként találták meg a hajóroncsban lévő holttesteket; készített interjúkat rendőrtisztekkel, temetői alkalmazottakkal és számtalan rotai lakossal. Megismerte azokat a helyi lakosokat, akik kezdeményezték a kapcsolatfelvételt a hansalai rokonokkal (a falu, ahonnan a vízbe fulladt emberek származtak). Hansalában beszélt özvegyekkel, testvérekkel, szülőkkel, akik abban reménykedtek, hogy visszakaphatják a hajóbaleset során eltűnt szeretteik testét és szülőföldjükön temethetik el őket.

A nyomok keresése szorosan összeolvad a nyomok leírásával. A jelöletlen fal a los barriosi temetőben annak a csendnek és némaságnak a jelképévé vált, amellyel gyak- 


\section{OLVASS FELESLEGESET!}

ran szembesült a kutatómunka során. A szerző odament, hogy megértse az üresség hangját, mint a halál hangos csendjét. Nem próbált hangot adni neki, de komolyan vette „csendes beszédüket”, azt a beszédet, amelyet nem hall senki, mégis halkan motoszkáló zajt idéz elő, finom kopogásként az élők csendjében. A halál nyomainak megírása egy kísérlet arra, hogy szavakba öntse a hiányzó szavak által keletkezett űrt. A probléma azonban a nyomok megírásával az, hogy azt kell megjelenítenie, amit nem lehet ábrázolni. A történteket nem lehet teljes egészében rekonstruálni. Magukat a nyomokat így a néprajzi ihletésű írások testesítik meg, amelyek noha nem próbálják meg a kisebb foszlányokat egésszé kovácsolni, sem felfoghatóvá tenni a felfoghatatlant, sokkal inkább arra törekednek, hogy feltárják a kifejezhetetlent, a bizonytalant és a befejezetlent.

A jelenlegi, tengeren hatályban lévő határrendészeti gyakorlat nem csak szelektíven korlátozza és engedi az emberek határokon történő mozgását, hanem egyúttal növeli a határátkelések veszélyességének kockázatát is (Albahari 2015). A korai 2000-es évek óta bevezetett nagyszámú határrendészeti szigorítások és megfigyelési technológiák fejlődése rákényszeríti a bevándorlókat, hogy jóval hosszabb és kockázatosabb utakat válasszanak „a tenger stratégiai használata közben” (Heller Pezzani 2017).

\section{Módszertan}

Annak érdekében, hogy fény derüljön a politikai felelőtlenségre, amely szerepet játszott a rotai hajóbaleset során és azt követően, az alábbi, a baleset során keletkezett dokumentációkat tanulmányozta a szerző:

A mentési események hangfelvételeiből készült leirat, amely betekintést enged a baleset időrendi történéseibe (Méndez 2004). Fényt derít továbbá azokra az infrastrukturális, intézményi és egyéb okokra, amelyek a mentőakció késedelmes megkezdésében játszhattak szerepet. Láthatóvá válik számos ember tétlensége és ennek igazolása.

A parti őség egyik jelentése, amely tartalmazza az ítéletet a két csempész ellen, akiket részben felelőssé tettek a rotai áldozatokért. Ez a dokumentum részletesen leírja, hogy mi történt a hajóbaleset során. Ez főleg a túlélők és a Focs Tenerife teherhajó (az első hajó, amelyik észlelte a Rota partjaihoz közel elsüllyedő vitorláshajót) kapitányának vallomásaira épül.

A spanyol állami intézmények online archívumai közül a képviselőház 2003. november 20-i leirata, amelyben a különböző hovatartozású pártok politikusai alaposan megvitatják a rotai hajóbaleset körülményeit. 


\section{OLVASS FELESLEGESET!}

\section{Törvények, újságcikkek}

\section{A POLITIKAI FELELŐTLENSÉG}

Kit lehet beperelni kártérítésért? A csempészt? A spanyol államot? Az EU-t? A marokkói államot? A tengert? Ki az elkövető?

A hajóbalesetet követően csupán Aziz E.-t, a csempészt találták megvádolhatónak. A bírósági jegyzőkönyv egyértelműen kimondja, hogy a büntető eljárást az érintettek (az elhunytak hozzátartozói) nevében indították el, valamint azt is kiköti, hogy a hozzátartozóknak lehetőségük van kártérítési igényt benyújtani Aziz E.-vel szemben. A családok azonban soha nem kértek kártérítést, ellenben a rotai lélekvesztő csempészei, akik segítettek megszervezni az utazást Marokkóban (de a hajóra nem szálltak fel), többször is megjelentek a faluban, hogy követeljék az út megszervezéséért járó pénzt. Ezt figyelembe véve nem meglepő, hogy a gyászoló családok a csempészeket tették felelőssé az egész tragédiáért. Tény, hogy a családoknak fizetniük kellett a spanyol-marokkói tengeren történő átkelésért, annak ellenére, hogy a hajó elsüllyedt, és az emberek nagy része sosem jutott el élve spanyol területre. Ezek után nem meglepő, hogy a csempészeket bűnösnek tartották kizsákmányolás és csalás vádjában.

A hajóbalesetet követő események során az állami szervek működésében semmilyen gondatlanság nem merült fel, és semmilyen méltánytalanság kapcsán nem marasztalták el azokat. Sem a Spanyol Tengerészeti és Mentési Szervezet (Sasemar), sem a Guardia Civil Szervezet, sem pedig a Tengerészeti Támaszpont nem vállalt semmilyen felelősséget az esettel kapcsolatban (De Genova 2017).

\section{A halál szövedékei}

A bevezetésben az a kérdés is felmerült, hogy hogyan tudunk néprajzi szemszögből kapcsolódni valakihez, aki halott, és hogyan lehetséges a halál zajos csendjéről írni. Ahhoz, hogy választ adhassunk ezekre a kérdésekre, nem szabad figyelmen kívül hagyni, hogy az élettelen testek olyan energiákat szabadíthatnak fel, amelyek a mai napig érezhetők azoknak az embereknek az esetében, akik közvetlenül találkoztak a halál jelenlétével, és akik részletesen idézték fel a holttestek borzalmas fizikai állapotát, noha egyáltalán nem is akartak beszélni erről. Az érzelemfelidéző energia olyan fogalom, amellyel érdemes komolyan foglalkozni (Navaro-Yashin 2009). Ezzel kapcsolatban többek között az is feltárásra került, hogy a halál hogyan ejti fogságba azokat, akik először találkoztak a holttestekkel, azáltal, hogy még hosszú idő eltelte után is vizuális, olfaktorikus és taktilis nyomokat hagynak az emlékezetükben. 


\section{Hallgatólagos csend}

Az elmúlt három évtizedben, az Európai Unió és a schengeni övezet megalakulásával az európai migrációs rendszer drámaian megváltozott, köszönhetően az európai külföldi határterületek túlbiztosításának, Európa határainak az afrikai kontinensre történő kivetítésének, a vízum és kitoloncolás rendszerének, valamint azoknak a megállapodásoknak köszönhetően, amelyek a migráció megakadályozására törekedtek (De Genova 2017). A határrendészet uralma nemcsak a halálban, hanem abban is testet ölt, hogy egy ilyen esemény emlékeivel csendben kell tovább élni, úgy, hogy a hátramaradt családok sosem találnak rá az áhított meghallgatásra.

\section{Egyetlen halál, többszörös veszteség}

A marokkói vizsgálat többnyire csak a felszínt érintette, nem sikerült annyira elmélyedni ezeken a területeken, mint ahogyan Spanyolországban; ennek ellenére a halottak nyomainak felkutatása a Gibraltár-szoroson keresztül Marokkóig láttatni engedte a rotai hajóbaleset transznacionális hatásait (Wimmer - Schiller 2002).

A disszertáció ismeretelméleti célja volt az is, hogy bemutassa, hogyan „működik" a gyász azáltal, ahogyan a családtagok emlékeznek, beszélnek a halottakról (Fontein 2016). Összehasonlítva azoknak az embereknek a tapasztalatait, akik el tudták temetni szeretteik holttestét, azokkal, akiknek erre nem volt lehetőségük, világosan kirajzolódik, hogy milyen jelentőséggel bír a holttest azonosítása és visszahonosítása, a temetési szertartás és a gyász folyamata, amely enyhíteni képes azon a fájdalmon, amit a halál okozott (Stoler 2008).

A holttest hazájába történő visszakerülése azonban nem minden esetben hoz megbékélést a gyászoló családnak, és negatív következményei is lehetnek, amely reménytelenséget és a jövőkép elvesztését jelentheti a család számára. Ugyanakkor, ha a család nem kapja vissza a holttestet, nem tudja eltemetni, és a sírkő mellett állva gyászolni, az egyfajta reményt és várakozást is jelenthet a mindennapokban (Stoler 2008).

A családok beszámolóiból kiderül, hogy a gyász, a veszteség, és a holttest szoros kapcsolatban vannak egymással. Egyúttal betekintést engednek abba, hogy az élők hogyan kötődnek érzelmileg és erkölcsileg azokhoz, akik már nincsenek közöttük.

$\mathrm{Az}$, hogy a gyász és a fájdalom idővel hogyan változik, gyakran kapcsolódik ahhoz, hogy fizikálisan hol van a holttest. Akik eltemették hozzátartozójukat, azok illendően tudtak gyászolni, és megnyugvást leltek (Weiss - Krejci 2013). Ezzel szemben, akik továbbra is bizonytalanságban élnek, és nem tudják, hogy mi lett a sorsa elvesztett rokonuknak, hajlamosak az átmenetiség állandósulását megtapasztalni, amely abban nyilvánul meg, hogy például az eltűnt gyermekek kortalanná válnak (Das 2007). 


\section{OLVASS FELESLEGESET!}

A holttestek eltűnése komoly érzelmi, szociális és gazdasági károkat okoz sokak számára. Míg a holttest a családok számára a vágyakozás tárgya (Borneman 2014), addig a rendőrség és az igazságügyi szakértők számára a holttest egy tudományos tárggyá válik, azoknak az azonosítási protokolloknak megfelelően, amelyek arra hivatottak, hogy az elhunyt személyazonosságáról minél több információhoz lehessen hozzájutni. Ráadásul maguk a rendőrök is teljesen érzelemmentesek maradnak, amikor holttestekkel találkoznak. Amint a holttest bekerül ebbe az adminisztrációs körforgásba, mindegy, hogy gyászolják-e vagy sem, egy személytelen tárggyá válik, amellyel tudományos és bürokratikus pontossággal bánnak (Perl 2016).

\section{Ami a gyász politikája mögött rejlik}

A rotai hajóbaleset negatív hatásai, mint például a bizonytalanság, a rosszindulat és a valós félelem állami szinten tétlenséghez és a segítség elutasításához vezettek (De Genova 2017). Ugyanakkor a gyász, különösképpen a mások gyászának felismerése, kiemelkedő jelentőséggel bír a politikai változások tekintetében (Butler 2009). Olyan érzelmi reakciók, mint az empátia, a harag, a bűnösség és a szégyen cselekvésre ösztönözték az embereket, s a közösen átélt emberiesség megtapasztalása, valamint a szociális és gazdasági egyenlőtlenségek érzékelése segítette egy transznacionális közösség kialakulását. A rotaiak és a hansalai rokonok összefogásának példája azt mutatja, hogy a kölcsönös kapcsolat az érzékenység/erkölcs és a politika/történelem között kiemelkedő jelentőségű, és a határokhoz való tartós kapcsolódás az, ami létrehozhat egy közösséget.

A rokonok összefogása és barátsága annak a 12 embernek köszönhetően alakult ki, akik a rotai hajóbalesetben veszítették életüket, és akiknek a halála a Gibraltári-szoros mindkét oldalán élő embereket egyaránt megérintette, valamint olyan reménykeltő politikai aktivitásokat gerjesztett, amelyek az empátián alapulnak.

\section{A halál nyomában}

A szerencsétlenség kapcsán fény derült arra is, hogy egy hajótörés hogyan bélyegzi meg a határmenti emberek életét, illetve melyek azok a legfontosabb intézményi és jogi változások, amelyek megerősítésre, vagy éppen bevezetésre kerültek a spanyolmarokkói és az európai-afrikai határokon (De Genova 2017).

Noha Spanyolország semmilyen felelősséget nem vállalt az esettel kapcsolatban, mégis történt néhány intézkedés. Megerősítették a mentési szolgálatot, több mentőmellény és csónak került alkalmazásra, illetve megújították a mentési terveket is. A határok megerősítése is megtörtént, amely fokozottabb ellenőrzést eredményezett. A spanyol határokon még nagyobb erőkkel igyekeztek megállítani az illegális bevándorlást. A spanyol állam tehát még szigorúbb törvényekkel és megerősített 


\section{OLVASS FELESLEGESET!}

mentési protokollokkal reagált a hajóbalesetre. Spanyolországban a fő cél az volt, hogy jobban kezeljék a kockázatokat, amelyeket a tengeren bekövetkező halál jelent, és amelyeket a szabálytalanul eljáró bevándorlók vállalnak. A spanyol határőrök és a mentőegységek manapság is úgy tekintenek a bevándorlókra, mint egy hajóbaleset potenciális áldozataira.

A gyászoló családok számára a hajóbaleset okozta lelki válság nem egy egyszeri, kivételes esemény, amely a tengeren történt, sokkal inkább egy soha véget nem érő érzés, amely az életük részéve vált. A bevándorlás során elszenvedett halál olyan esemény, amely rátelepedik a mindennapokra.

Ennek az egy balesetnek a jelentősége abban rejlik, hogy utóhatásaiban milyen széles körű reakciókat eredményezett. Fordulópontot hozott nemcsak a nemzeti, de az európai határrendészeti rendszerben is, és megmutatta, hogy az európai bio- és nekropolitika szerinti „hagyjuk meghalni” szemlélet megrémítette az embereket a Földközi-tenger déli és északi szélein. Azt is megmutatta, hogyan maradt fenn az érzelmi, szociális, politikai és történelmi kapcsolat Spanyolország és Marokkó, valamint Európa és Afrika között. Vajon hány másik hajó története süllyedt el azokkal az emberekkel együtt, akik kezükbe vették saját sorsukat, és családjaik érdekében, egy jobb élet reményében ilyen kockázatot vállaltak?

Ahogyan a történelemben is láthatjuk, a halottak általában nem maradnak csendben. Néma beszédük beárnyékolja a komfortzónánkat, és válaszokat követelnek tőlünk. Talán ezek a halottak, a „mi” halottaink egyszer menekültgyilkosságok áldozataiként lesznek emlegetve. És egy napon azok, aki utánunk következnek majd, és akik őutánuk következnek, hangosan és kitartóan teszik majd fel, sürgető választ várva, a szégyenteljes kérdést: Hogy történhetett meg mindez?

\section{Irodalom}

Albahari, M. (2015): Crimes of Peace. Mediterranean Migrations at the World's Deadliest Border. Philadelphia, University of Pennsylvania Press.

Borneman, J. (2014): „Abandonment and Victory in Relations with Dead Bodies.” In: Stepputat, F. (ed.): Governing the Dead. Sovereignty and the Politics of Dead Bodies. Manchester, Manchester University Press, 229-249.

Butler, J. (2009): Frames of war. When is life grievable? London and New York, Verso.

Bachelet, S. (2016): Irregular sub-Saharan migrants in Morocco: (im)mobility, illegality and „adventure” in Rabat. University of Edinburgh, Unpublished Dissertation Thesis.

Fassin, D. (2015): „Troubled Waters: At the Confluence of Ethics and Politics.” In: Lambek, M. - Das, V. - Fassin, D. - Keane, W. (eds.): Four Lectures on Ethics: Anthropological Perspectives. Masterclass Series. . Chicago, Hau Books, 175-210. 


\section{OLVASS FELESLEGESET!}

Das, V. (2006): Life and Words Violence and the Descent into the Ordinary. Oakland, University of California Press.

De Genova, N. (2017): The Borders of 'Europe': Autonomy of Migration, Tactics of Bordering. Durham and London, Duke University Press.

Fontein, J. (2016): „Remaking the Dead, Uncertainty and the Torque of Human Materials in Northern Zimbabwe." In: Stepputat, F. (ed.): Governing the Dead. Sovereignty and the Politics of Dead Bodies. Manchester, Manchester University Press, 114-140.

Heller, C. - L. Pezzani (2017): „Liquid Traces: Investigating Deaths of Migrants at the EU's Maritime Frontier". In: De Genova, N. (ed.): The Borders of "Europe": Autonomy of Migration, Tactics of Bordering. Durham and London, Duke University Press, 95-119.

Malpas, J. (2012): „Fragility and Responsibility (Fragilidad y Responsabilidad).” In: Birulés, F. - Gómez Ramos, A. - Roldán, C. (eds.): Vivir Para Pensar. Barcelona Paidos, 65-74.

Méndez, R. (2004): „Las Grabaciones del Naufragio de Rota reflejan Descoordinación y Falta de Medios." El País, 2 February. https://elpais.com/diario/2004/02/02/espana/1075676402_850215.html (Letöltve: 2020. 08. 21.)

Navaro-Yashin, Y. (2009): „Affective Spaces, Melancholic Objects: Ruination and the Production of Anthropological Knowledge." Journal of the Royal Anthropological Institute (N.S.) 15: 1-18.

O’Neill, K. (2012): „There is no more room: Cemeteries, personhood, and bare death.” Ethnography 13(4): 510-530.

Perl, G. (2016): „Uncertain Belongings: Absent Mourning, Burial, and Post-mortem Repatriations at the External Border of the EU in Spain." Journal of Intercultural Studies 37(2): 195-209.

Perl, G. (2018): „Lethal Borders and the translocal politics of 'ordinary people.'” Journal of European Cultures 27(2): 85-104.

Stoler, A. L. (2008): „Imperial Debris: Reflections on Ruins and Ruination.” Cultural Anthropology 23(2): 191-219.

Weiss-Krejci, E. (2013): „The unburied dead.” In: Tarlow, S. - Nilsson Stutz, L. (eds.): The Oxford hand-book of the archaeology of death and burial, edited by. Oxford, Oxford University Press, 281-301.

Wimmer, A. - Glick Schiller, N. (2002): „Methodological nationalism and beyond: nationstate building, migration and the social sciences." Global Networks 2(4): 301-334. 